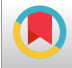

\title{
Prevalence of Hepatitis C Virus in Iranian Prisoners: An Updated Systematic Review and Multilevel Meta-Analysis Study
}

\author{
Alireza Najimi (iD ${ }^{1}$, Mohammad Gholami-Fesharaki (iD ${ }^{1,}{ }^{*}$ and Mohsen Rowzati ${ }^{2}$ \\ ${ }^{1}$ Department of Biostatistics, Faculty of Medical Sciences, Tarbiat Modares University, Tehran, Iran \\ ${ }^{2}$ Occupational Health Center, Isfahan Mobarakeh Steel Company, Isfahan, Iran \\ "Corresponding author: Department of Biostatistics, Faculty of Medical Sciences, Tarbiat Modares University, Tehran, Iran. Email: mohammad.gholami@modares.ac.ir
}

Received 2020 February 24; Accepted 2020 March 15.

\begin{abstract}
Context: Hepatitis $\mathrm{C}$ is one of the most dangerous viral infections causing chronic liver disease.

Objectives: The current study aimed to estimate the pooled prevalence of hepatitis C in Iranian prisoners.

Evidence Acquisition: Articles were identified through searching international databases, including PubMed, Scopus, Elsevier, Google Scholar, and Web of Science and Iranian databases, including Scientific Information Database (SID), Health.barakatkns, IranDoc, Civilica, and MagIran. We systematically reviewed all studies reporting the prevalence of HCV in Iranian prisoners. All studies conducted ELISA tests for the evaluation of HCV antibodies. In this study, a multilevel meta-analysis method was used to estimate the pooled prevalence.

Results: The electronic search identified 147 records, 33 of which were relevant papers used for the pooled meta-analysis of HCV prevalence. Overall, the prevalence of HCV using a multilevel meta-analysis approach was $24.88 \%$ (95\% CI=19.12 - 31.69). The highest pooled HCV rate was related to Markazi province (59.47\% [95\% CI = 51.70 - 67.25]), while the lowest pooled HCV rate belonged to North Khorasan province (5.00\% [95\% CI = 2.44 - 7.55]). A decreasing HCV prevalence trend was observed between 1995 and 2018.

Conclusions: The results of the study showed that the prevalence of HCV is significantly high among prisoners in Iran. An enhanced training program is needed for prisoners and prison staff to improve the prisoners' health status.
\end{abstract}

Keywords: Hepatitis C, Iran, Prevalence, Epidemiology, Multilevel Analysis, Prisoner, Systematic Review

\section{Context}

Hepatitis C Virus (HCV) is a major public health problem. It is associated with morbidity and mortality and imposes a substantial burden on the worldwide healthcare system $(1,2)$. About 399,000 people die each year due to hepatitis $C$, mostly from cirrhosis and hepatocellular carcinoma. A previous study estimated 71 million people (1\% of the world's population) living with HCV infection in 2015 (3).

Based on the available data, most countries in the Middle East and North Africa (MENA) have a low-to-moderate anti-HCV prevalence (4). A prison is a high-risk place for prisoners who are engaged in risky behaviors such as injecting drugs, tattooing, unwanted sexual intercourse, and sharing syringes. The HCV prevalence is generally higher among prisoners than in the general population, mainly due to risky behaviors of prisoners (5-7). Prisoners are susceptible to various infectious diseases and may spread them after they return to society (8). Information about the $\mathrm{HCV}$ prevalence in prisoners can lead to appropriate deci- sions in public health policy and management.

The previous meta-analysis of HCV prevalence among Iranian prisoners was done by Behzadifar et al. (9) in 2018. Two other studies did not use two rounds of a national study (bio-behavioral and observational studies of HBV and HCV in Iran prisons) conducted in 2015 and 2016 $(10,11)$ and not reported the prevalence of HCV by province.

\section{Objectives}

This systematic review and meta-analysis study was done to estimate the pooled HCV prevalence using a new statistical approach (multilevel meta-analysis) in prisoners.

\section{Evidence Acquisition}

\subsection{Search Strategy}

All studies used ELISA tests for assessing HCV antibodies. The literature on the HCV-Ab prevalence in Iran was 
acquired through searching international databases, including PubMed, Scopus, Elsevier, Google Scholar, and Web of Science and Iranian databases, including Scientific Information Database (SID), IranDoc, Health.barakatkns, MagIran, and Civilica. Our last search was conducted on February 8, 2020. To search and include related studies as many as possible, we used the terms "Hepatitis C", "HCV", "Prevalence”, "Epidemiology", "Prison", "Prisoner", "Inmates”, "Jails”, and "Iran” (or the names of its provinces) as keywords in titles and/or abstracts in the MeSH word search database.

\subsection{Selection of Studies and Data Extraction}

Published studies were regarded as qualified for the analysis if they met the following criteria: (1) crosssectional studies with the full text of the paper available in the Persian or English languages, (2) studies with a sample size of more than 30, and (3) studies reporting the prevalence of HCV antibodies by the ELISA test in Iran provinces. Conversely, the following studies were excluded: (1) nonEnglish or non-Persian full-text reports, (2) studies not providing enough data to estimate the prevalence rate, (3) studies designed as letters to the editor, expert opinions, editorials, commentaries, case-reports, case-series, and reviews, and (4) Studies reporting overlapping data.

\subsection{Data Extraction}

All articles categorized as potentially relevant were reviewed separately by both of the authors (Mohsen Rowzati and Alireza Najimi-Varzaneh). They evaluated the relevance of each report and summarized the following data using Excel datasheets: First author's name, year of publication, year of study, number of HCV patients, study sample size, name of the province, and mean age of responders. The analysis was conducted according to the preferred reporting items for systematic reviews and metaanalyses (PRISMA) (12). In this study, "The Newcastle Ottawa Scale (NOS)" was used to assess the quality of the included studies. For better data extraction, we used blinding and task separation (13).

\subsection{Statistical Analysis}

In the current meta-analysis study, two approaches were applied for data analysis. First, we used the "metafor" package in $\mathrm{R}$, version 3.6, software. In this technique, the heterogeneity among the studies was assessed using the $\mathrm{Q}$ test $(\mathrm{P}<0.10)$ and I-squared statistics (I2 > 40\%). According to the results of the heterogeneity test, we used fixed or random-effect models to determine the prevalence of HCV. According to the central limit theorem, to estimate the pooled effect $(\theta)$ in the fixed-effects model, the prevalence of hepatitis C in each study $\left(p_{i}\right)$ is assumed to be homogeneous (homogeneity assumption) with normal distribution and a mean of $\theta$ and variance of $V_{i}$ while in the random-effects model, the homogeneity assumption is violated. The other main assumption for the conventional meta-analysis approach (fixed or random-effects) is the independence of studies (14). This assumption cannot be achieved in prevalence studies because studies that are from the same location are dependent on each other (14).To solve such problems, we proposed a multi-level meta-analysis method with the "lme4" package considering $\operatorname{Logit}\left(p_{i j k}\right)=\omega+u_{j(i)}+v_{i}$, in which $u_{j(i)}$ and $v_{i}$ are random effects for study homogeneity and location dependency, respectively. After estimating $\omega$, the pooled effect $(\theta)$ was calculated with $\theta=\exp (\omega) /(1+\exp (\omega))$.

\section{Results}

\subsection{Search Results and Study Selection}

The study selection process is depicted in Figure 1. A total of 147 studies were potentially associated with the prevalence of HCV in Iran provinces. After reviewing the abstracts and titles, 98 studies were eliminated based on the stated inclusion and exclusion criteria. After the fulltext screening and quality assessment, a total of 33 records were deemed as eligible studies published until 2019.

\subsection{Prevalence of Hepatitis C Virus in Iranian Prisoners}

Table 1 presents the study characteristics, including the reference, province, first author's name, year of publication, year of study, mean age, number of HCV patients, and study sample size. Table 2 represents the pooled prevalence of hepatitis $C$ according to the prevalence in each province of Iran, as well as the pooled prevalence obtained by the multilevel meta-analysis. As can be seen, the pooled prevalence of $\mathrm{HCV}$ in prisoners was $24.88 \%$ with a $95 \%$ Confidence Interval (CI) of $19.12 \%-31.69 \%$. The results also showed a decreasing trend in the HCV prevalence between 1995 and 2018.

\section{Discussion}

The findings of this study showed that the estimated prevalence of HCV among Iranian prisoners was $24.88 \%$ (number of studies $=33$ ). This rate is lower than the rate reported in Behzadifar et al. study (9) (number of studies $=17$, reported $\mathrm{HCV}$ prevalence $=28 \%$ ). Such a difference can be attributed to the number of studies used in the metaanalysis and the use of a powerful statistical approach. In the multilevel meta-analysis, the heterogeneity of each province can be corrected from the overall pooled effect, 


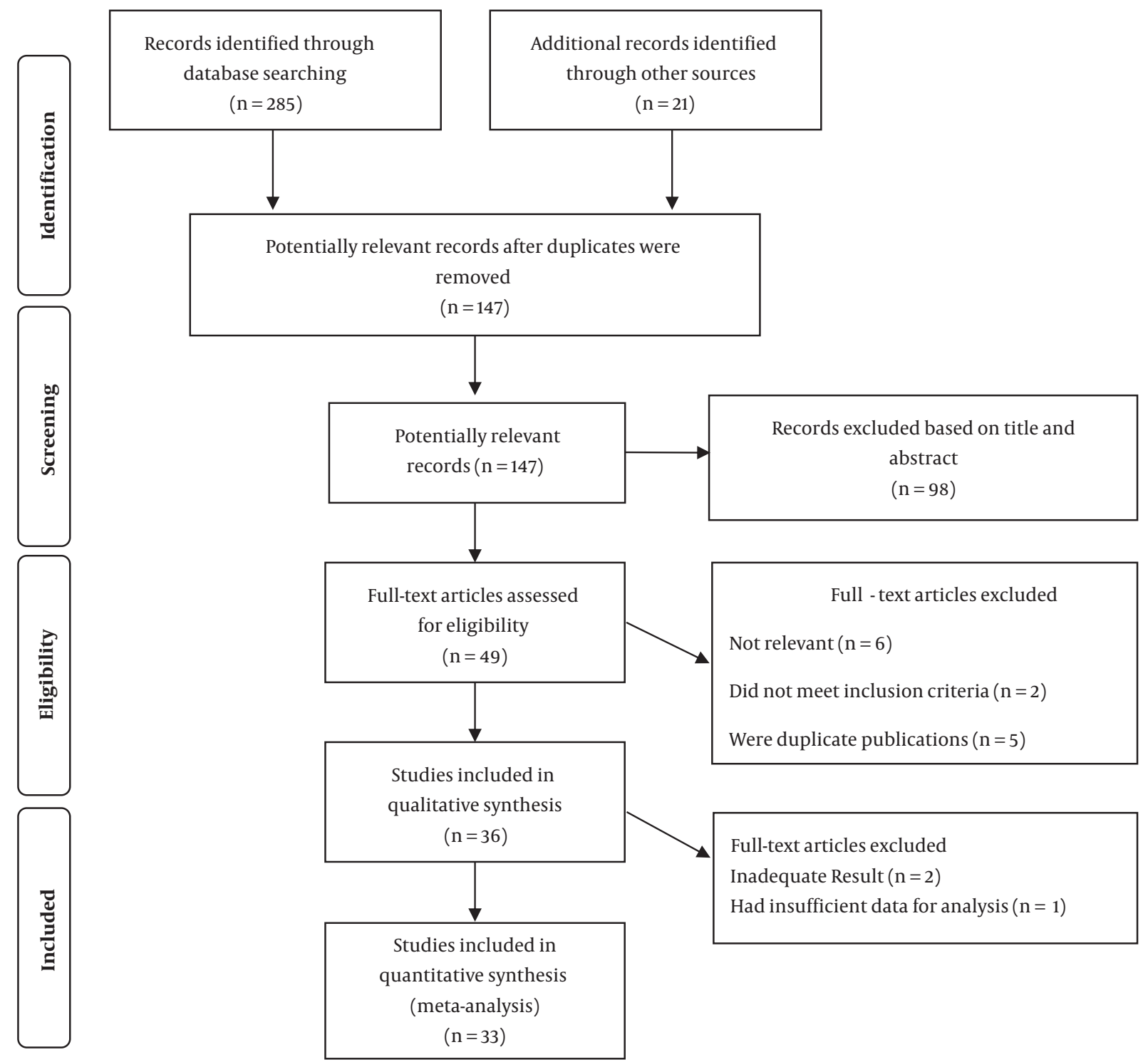

Figure 1. Screening of Articles Based on PRISMA Statement

and the estimation of the pooled effect is reported with higher accuracy (14). Previously published meta-analysis studies have reported the HCV prevalence in different subsets of the Iranian population. This rate is higher than the prevalence in the general population (reported HCV prevalence $=0.6 \%)(46)$ and lower than the rate among people who inject drugs (reported HCV prevalence $=52.2 \%$ ) (1). In comparison with the international studies, this rate is higher than the prevalence reported among prisoners in Egypt (23.6\%), Pakistan (15.6\%), Libya (23.7\%) (47), Italy (22.4\%) (48) Brazil (2.4\%) (49), France (4.8\%) (50), the United
States (18\%)(51), and Hungary (4.9\%)(52) and lower than the rate in California (34.3\%) (8), Indonesia (34.1\%)(53), Lebanon (28.1\%) (47), and Irish prisoners (37\%) (54).

Differences in the prevalence of HCV in different studies are due to differences in the type of prisons and prisoners. Most prisoners are at risk of hepatitis due to high-risk behaviors such as injecting drugs, addiction, sexual misconduct, and violence (19). On the other hand, prisoners are not isolated from society; many prisoners are kept for a short period, and many of them return to the community and contact with the general public. This makes hepatitis $C$ 


\begin{tabular}{|c|c|c|}
\hline Province & Number of Studies & Prevalence (95 CI) \\
\hline Alborz & 2 & $8.58(3.32-13.85)$ \\
\hline Azerbaijan, East & 6 & $18.56(10.75-26.38)$ \\
\hline Bushehr & 2 & $41.29(37.78-44.79)$ \\
\hline $\begin{array}{l}\text { Chaharmahal and } \\
\text { Bakhtiari }\end{array}$ & 3 & $18.10(5.99-30.20)$ \\
\hline Fars & 2 & $10.34(4.34-16.35)$ \\
\hline Guilan & 2 & $21.29(19.22-23.47)$ \\
\hline Golestan & 1 & $23.14(15.62-30.65)$ \\
\hline Hamadan & 2 & $21.78(5.88-37.67)$ \\
\hline Hormozgan & 2 & $14.32(11.95-16.96)$ \\
\hline Isfahan & 8 & $34.30(21.06-47.54)$ \\
\hline Kerman & 2 & $5.27(1.09-9.45)$ \\
\hline Kermanshah & 5 & $24.23(14.42-34.05)$ \\
\hline Khorasan, North & 1 & $5.00(2.44-7.55)$ \\
\hline Khorasan, Razavi & 9 & $33.66(22.73-44.60)$ \\
\hline Khorasan, South & 4 & $7.83(6.64-9.03)$ \\
\hline Khuzestan & 1 & $11.30(9.30-13.30)$ \\
\hline $\begin{array}{l}\text { Kohgiluyeh and } \\
\text { Boyer-Ahmad }\end{array}$ & 2 & $9.78(7.79-12.07)$ \\
\hline Kurdistan & 1 & $26.25(21.94-30.56)$ \\
\hline Lorestan & 2 & $26.84(24.16-29.66)$ \\
\hline Markazi & 1 & $59.47(51.70-67.25)$ \\
\hline Mazandaran & 2 & $17.18(14.47-20.16)$ \\
\hline Qazvin & 1 & $11.58(8.82-14.33)$ \\
\hline Sistan and Baluchestan & 2 & $10.09(7.72-12.45)$ \\
\hline Tehran & 6 & $48.72(19.37-78.08)$ \\
\hline Yazd & 1 & $5.06(2.57-7.56)$ \\
\hline Zanjan & 5 & $56.73(51.96-61.50)$ \\
\hline Multilevel Pooled Effect & & $24.88(19.12-31.69)$ \\
\hline
\end{tabular}

prisoners a risk group for HCV transmission to the community. Therefore, paying attention to the prevalence of hepatitis $\mathrm{C}$ among prisoners can guarantee community health (19).

Our results also showed a decreasing trend in the HCV prevalence between 1995 and 2018 (Figure 2). Such a reduction can be the result of implementing educational programs and effective therapeutic strategies targeting hepatitis $C$ by the Ministry of Health.

Some limitations exist in the present study, the first of which is not mentioning the type of prisoners in the published articles, and the second is the lack of data and studies from some provinces.

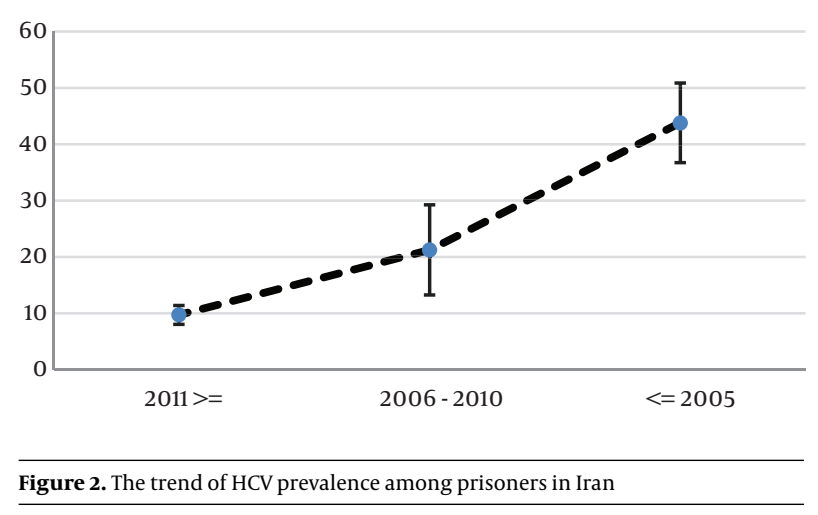

Two strong points of this study are the use of two rounds of a national study conducted in 2015 and 2016 (10, 11) and the use of a new statistical approach (multilevel meta-analysis) for calculating the pooled effect.

\section{Conclusions}

According to this study, hepatitis $\mathrm{C}$ has a high prevalence among prisoners in Iran. Consequently, we recommend the regular screening of prisoners, separating the affected prisoners from the rest, taking remedial measures including easy access to disposable syringes and needles, health education (personal and community), and treatment of addicted prisoners.

\section{Acknowledgments}

The authors gratefully acknowledge the financial support of Tarbiat Modares University.

\section{Footnotes}

Authors' Contribution: M. GH.F.: data analysis and study supervision; A. N.: data collection and manuscript writing; M. R.: data collection

Conflict of Interests: The authors declare that they have no conflict of interest.

Ethical Approval: IR.MODARES.REC.1397.254.

Funding/Support: Tarbiat Modares University funded the study.

\section{References}

1. Mahmud S, Akbarzadeh V, Abu-Raddad LJ. The epidemiology of hepatitis C virus in Iran: Systematic review and meta-analyses. Sci Rep. 2018;8(1):17-18296. doi: 10.1038/s41598-017-18296-9. 
2. Shepard CW, Finelli L, Alter MJ. Global epidemiology of hepatitis C virus infection. Lancet Infect Dis. 2005;5(9):558-67. doi: 10.1016/S14733099(05)70216-4.

3. Blach S, Zeuzem S, Manns M, Altraif I, Duberg A, Muljono DH, et al. Global prevalence and genotype distribution of hepatitis $C$ virus infection in 2015: a modelling study. The Lancet Gastroenterology \& Hepatology. 2017;2(3):161-76. doi:10.1016/S2468-1253(16)30181-9.

4. Chaabna K, Cheema S, Abraham A, Alrouh H, Lowenfels AB, Maisonneuve $\mathrm{P}$, et al. Systematic overview of hepatitis $\mathrm{C}$ infection in the Middle East and North Africa. World journal of gastroenterology. 2018;24(27):3038-54. doi: 10.3748/wjg.v24.i27.3038. [PubMed: 30038471].

5. Reindollar RW. Hepatitis $\mathrm{C}$ and the correctional population. The American journal of medicine. 1999;107(6):100-3. doi: 10.1016/So0029343(99)00394-0.

6. Larney S, Kopinski H, Beckwith CG, Zaller ND, Jarlais DD, Hagan H, et al. Incidence and prevalence of hepatitis $\mathrm{C}$ in prisons and other closed settings: results of a systematic review and meta-analysis. Hepatology. 2013;58(4):1215-24. doi: 10.1002/hep.26387.

7. Vescio MF, Longo B, Babudieri S, Starnini G, Carbonara S, Rezza $\mathrm{G}$, et al. Correlates of hepatitis $\mathrm{C}$ virus seropositivity in prison inmates: a meta-analysis. Journal of Epidemiology \& Community Health 2008;62(4):305-13. doi: 10.1136/jech.2006.051599.

8. Fox RK, Currie SL, Evans J, Wright TL, Tobler L, Phelps B, et al. Hepatitis $C$ virus infection among prisoners in the California state correctional system. Clinical Infectious Diseases. 2005;41(2):177-86. doi: $10.1086 / 430913$.

9. Behzadifar M, Gorji HA, Rezapour A, Bragazzi NL. Prevalence of hepatitis $C$ virus infection among prisoners in Iran: a systematic review and meta-analysis. Harm reduction journal. 2018;15(1):24. doi: 10.1186/s12954-018-0231-0.

10. Moradi G, Gouya M, Azimizan Zavareh F, Mohamadi Bolbanabad A, Darvishi S, Aghasadeghi MR, et al. Prevalence and risk factors for HBV and HCV in prisoners in Iran: a national bio-behavioural surveillance survey in 2015. Tropical Medicine \& International Health. 2018;23(6):6419. doi: 10.1111/tmi.13065.

11. Moradi G, Jafari S, Zarei B, Mahboobi M, Zavareh FA, Molaei L, et al. Prevalence and Risk Factors for Hepatitis B and Hepatitis C Exposure in Iranian Prisoners: A National Study in 2016. Hepatitis Monthly 2019;19(7). doi: 10.5812/hepatmon.91129.

12. Moher D, Shamseer L, Clarke M, Ghersi D, Liberati A, Petticrew M, e al. Preferred reporting items for systematic review and meta-analysis protocols (PRISMA-P) 2015 statement. Systematic Reviews. 2015;4(1):1 doi: 10.1186/2046-4053-4-1.

13. Salehi-Vaziri M, Sadeghi F, Almasi Hashiani A, Gholami Fesharaki M, Alavian SM. Hepatitis B Virus Infection in the General Population of Iran: An Updated Systematic Review and Meta-Analysis. Hepatitis Monthly. 2016;16(4). e35577. doi: 10.5812/hepatmon.35577. [PubMed Central: PMC4888501].

14. Scammacca N, Roberts G, Stuebing KK. Meta-Analysis With Complex Research Designs: Dealing With Dependence From Multiple Measures and Multiple Group Comparisons. Review of educational research. 2014;84(3):328-64. doi: 10.3102/0034654313500826. [PubMed: 25309002].

15. Sharafi H, Poustchi H, Azimian F, Tamadoni B, Ramezani R, Gouya MM, et al. Performance of a rapid diagnostic test for screening of hepatitis $\mathrm{C}$ in a real-life prison setting. Journal of Clinical Virology. 2019;113:20-3. doi:10.1016/j.jcv.2019.02.005.

16. Asgari F, Gouya MM, Mohammad K, Fotouhi A, Yousefi AA. Hepatitis C virus infection among Iranian prisoners and its relation with addiction, 2001-2005[Persian]. Hakim research journal. 2008;11(1):1-8.

17. Naghili B, Mohammad shahi J. Prevalence of Hepatitis $C$ infections in Tabriz prisoners[Persian]. Iranian Journal Of Infectious Diseases And Tropical Medicine. 2012;17(58):25-30.

18. Tajbakhsh E, Paiedar F. Seroepidemiological study of hcv infections in shahrekord jail prisoners[Persian]. Journal of microbial world.
2008;1(1):23-8.

19. Alasvand R, Azimian F, Hosseini-Zijoud S, Dashbolagh FA, ParsaMahjoob M, Nabavi M. Prevalence of hepatitis B and C in male prisoners in Iranian prisons. Int J Travel Med Glob Health. 2015;3(4):183-6. doi: 10.20286/IJTMGH-0304112.

20. Amiri ZM, Rezvani M, Shakib RJ, Shakib AJ. Prevalence of hepatitis $C$ virus infection and risk factors of drug using prisoners in Guilan province. EMHJ - Eastern Mediterranean Health Journal. 2007;13(2):2506. [PubMed Central: PMC17684845].

21. Behnaz K, Abdollah A, Fateme F, Mohammadreza R. Prevalence and risk factors of HIV, hepatitis $B$ virus and hepatitis $C$ virus infections in drug addicts among Gorgan prisoners. Journal of Medical Sciences. 2007;7(2):252-4. doi:10.3923/jms.2007.252.254.

22. Alizadeh AHM, Alavian SM, Jafari K, Yazdi N. Prevalence of hepatitis $\mathrm{C}$ virus infection and its related risk factors in drug abuser prisoners in Hamedan-Iran. World journal of Gastroenterology: WJG. 2005;11(26):4085. doi: 10.3748/wjg.v11.i26.4085.

23. Davoodian P, Dadvand H, Mahoori K, Amoozandeh A, Salavati A. Prevalence of selected sexually and blood-borne infections in Injecting drug abuser inmates of bandar abbas and roodan correction facilities, Iran, 2002. Brazilian Journal of Infectious Diseases. 2009;13(5):3568. doi: 10.1590/S1413-86702009000500008.

24. Ataei B, Babak A, Yaran M, Kassaian N, Nokhodian Z, Meshkati M, et al. Hepatitis C in Intravenous Drug Users: Seroprevalence and Risk Factors[Persian].Journal of Isfahan Medical School.2011;28(Special Issue on Hepatitis C):1537-45.

25. Kassaian N, Adibi P, Kafashaian A, Yaran M, Nokhodian Z, Shoaei P, et al. Hepatitis $C$ virus and associated risk factors among prison inmates with history of drug injection in Isfahan, Iran. Int J Prev Med. 2012;3(Suppl1). S156. [PubMed Central: PMC22826759].

26. Nokhodian Z, Ataei B, Kassaian N, Yaran M, Hassannejad R, Adibi P. Seroprevalence and risk factors of hepatitis $C$ virus among juveniles in correctional center in Isfahan, Iran. International journal of preventive medicine. 2012;3(Suppl1). S113. [PubMed Central: PMC3399313].

27. Nokhodian Z, Yazdani MR, Yaran M, Shoaei P, Mirian M, Ataei B, et al. Prevalence and risk factors of HIV, syphilis, hepatitis B and C among female prisoners in Isfahan, Iran. Hepat Mon. 2012;12(7):442. doi: 10.5812/hepatmon.6144. [PubMed Central: PMC3437455].

28. Javadi AA, Avizhgan M, Hafizi M. Prevalence of HBV and HCV infections and associated risk factors in addict prisoners. Iranian journal of public health. 2006;35(4):33-6.

29. Khademi N, Skakiba E, khodadoust M, Khoramdad M. Seroprevalence and Related Risk Behaviors of Hepatitis C, Hepatitis B and HIV Infections among Male Prisoners in Kermanshah, Iran. Arch Iran Med. 2019;22(10):588-91. [PubMed Central: PMC31679361].

30. Ghorbani A, Masoudifar M, Tasbandi R, Mirmousavi SJ, Ebadollahzadeh H. Prevalence of hepatitis B in the city of Sabzevar prisoners from 2004 to 2006. 16th Iranian Conference on Infectious Diseases and Tropical Medicine. Tehran, Iran. 2008.

31. Khajedaluee M, Babaei A, Vakili R, Valizade N, Homaei Shandiz F, Alavian SM, et al. Sero-Prevalence of Bloodborne Tumor Viruses (HCV, HBV, HTLV-I and KSHV Infections) and Related Risk Factors among Prisoners in Razavi Khorasan Province, Iran, in 2008. Hepat Mon. 2016;16(12). e31541. doi: 10.5812/hepatmon.31541. [PubMed: 28123439]. [PubMed Central: PMCPmc5237471].

32. Rowhani-rahbar A, Tabatabaei yazdi A, Panahi M. Prevalence of common blood-borne infections among imprisoned injection drug users. Archives of iranian medicine. 2004;7(3).

33. Azarkar Z, Sharifzadeh G. Evaluation of the Prevalence of Hepatitis B, Hepatitis C, and HIV in Inmates with Drug-Related Convictions in Birjand, Iran in 2008. Hepat Mon. 2010;10(1):26-30. [PubMed: 22308122]. [PubMed Central: PMCPmc3270341].

34. Azarkar Z, Sharifzadeh G, Miraki MA. HBV, HCV and HIV prevalence among - south Khorasan prisoners[Persian]. J Birjand Univ Med Sci. 2007;14(2):9-15. 
35. Ghafari S, Sharifzadeh G, Jamali S, Taji B, Javadmoosavi SY, Ziaee M. Prevalence of Hepatitis B and C among Drug-Abusing Male Prisoners in Birjand, South Khorasan, Iran. Archives of Iranian Medicine (AIM). 2019;22(9). [PubMed Central: PMC31679371].

36. Ziaee M, Sharifzadeh G, Namaee MH, Fereidouni M. Prevalence of HIV and hepatitis B, C, D infections and their associated risk factors among prisoners in Southern Khorasan Province, Iran. Iranian journal of public health. 2014;43(2):229. [PubMed Central: PMC4450691].

37. Sarkari B, Eilami O, Khosravani A, Sharifi A, Tabatabaee M, Fararouei $M$. High prevalence of hepatitis $C$ infection among high risk groups in Kohgiloyeh and Boyerahmad Province, Southwest Iran. Arch Iran Med. 2012;15(5):271-4. [PubMed: 22519374].

38. Sofian M, Aghakhani A, Banifazl M, Azadmanesh K, Farazi A, McFarland W, et al. Viral hepatitis and HIV infection among injection drug users in a central Iranian City. Journal of addiction medicine. 2012;6(4):292-6. doi: 10.1097|ADM.ob013e3182659928.

39. Zakizadeh M, Sadeghian AA, Bagheri Nesami M, Mohammadpour Tahamtan RA, Salmeh F, Yaghoubi T, et al. Seroprevalence of hepatitis c infection and associated factors in addicts imprisoned at khezrabad prison, sari. SSU_Journals. 2006;14(2):29-37.

40. Salehi, Saneei moghadam E, Ansari moghadam AR. Frequency of HBsAg and hepatitis C infection in prisoners in Sistan and Baluchestan province. Zahedan Journal of Research in Medical Sciences. 2001;3(4):915.

41. MohammadMehdi M, Ashraf M, Hamid T, Esmaeil A, Hossein P. Incarceration is a major risk factor for blood-borne infection among intravenous drug users. Hepatitis Monthly. 2011;2011(1, Jan):19-22. [PubMed Central: PMC3206659].

42. Mir-Nasseri S, Poustchi $H$, Nasseri-Moghadam S, Nouraie S, Tahaghoghi S, Afshar P, et al. HCV in intravenous drug users. Govaresh. 2005;10(2):80-6.

43. Mirnaseri $S$, poustchi $\mathrm{H}$, naseri MS, tavakoli $\mathrm{H}$, mohammad KA, afshar $\mathrm{P}$, et al. Hepatitis $\mathrm{C}$ seroprevalence among intravenous drug users in Tehran. Journal of research in medical sciences (jrms). 2008;13(6):295302.

44. Zali MR, Aghazadeh R, Nowroozi A, Amir-Rasouly H. Anti-HCV antibody among Iranian IV drug users: is it a serious problem? Arch Irn Med. 2001;4(3):115-9.

45. Khani M, Vakili M. Prevalence and risk factors of hiv, hepatitis b virus and hepatitis c virus infections in drug addicts among zanjan prison- ers. Archives of iranian medicine. 2003;6(1):1-4

46. Mirminachi B, Mohammadi Z, Merat S, Neishabouri A, Sharifi AH, Alavian $\mathrm{SH}$, et al. Update on the prevalence of hepatitis $\mathrm{C}$ virus infection among Iranian general population: a systematic review and metaanalysis. Hepatitis Monthly. 2017;17(2). doi: 10.5812/hepatmon.42291.

47. Heijnen M, Mumtaz GR, Abu-Raddad LJ. Status of HIV and hepatitis $C$ virus infections among prisoners in the Middle East and North Africa: review and synthesis. Journal of the International AIDS Society. 2016;19(1):20873. doi: 10.7448/IAS.19.1.20873. [PubMed: 27237131].

48. Brandolini M, Novati S, De Silvestri A, Tinelli C, Patruno SFA, Ranieri R, et al. Prevalence and epidemiological correlates and treatment outcome of HCV infection in an Italian prison setting. BMC Public Health. 2013;13(1):981. doi: 10.1186/1471-2458-13-981.

49. Puga MAM, Bandeira LM, Pompilio MA, Croda J, de Rezende GR, Doris bor LFP, et al. Prevalence and incidence of HCV infection among prisoners in Central Brazil. PloS one. 2017;12(1). e0169195. doi: 10.1371/journal.pone.0169195.

50. Semaille C, Le Strat Y, Chiron E, Chemlal K, Valantin MA, Serre P, et al. Prevalence of human immunodeficiency virus and hepatitis $C$ virus among French prison inmates in 2010: a challenge for public health policy. Eurosurveillance. 2013;18(28):20524. doi: 10.2807/15607917.ES2013.18.28.20524.

51. Spaulding AC, Anderson EJ, Khan MA, Taborda-Vidarte CA, Phillips JA. HIV and HCV in U.S. Prisons and Jails: The Correctional Facility as a Bellwether Over Time for the Community's Infections. AIDS reviews. 2017;19(3):134-47. doi: 10.24875/AIDSRev.M17000006. [PubMed 28926560]

52. Tresó B, Barcsay E, Tarján A, Horváth G, Dencs Á, Hettmann A et al. Prevalence and correlates of HCV, HVB, and HIV infection among prison inmates and staff, Hungary. Journal of Urban Health. 2012;89(1):108-16. doi: 10.1007/s11524-011-9626-X.

53. Prasetyo AA, Dirgahayu P, Sari Y, Hudiyono H, Kageyama S. Molecular epidemiology of HIV, HBV, HCV, and HTLV-1/2 in drug abuser inmates in central Javan prisons, Indonesia. The Journal of Infection in Developing Countries. 2013;7(6):453-67. doi: 10.3855/jidc.2965.

54. Allwright S, Bradley F, Long J, Barry J, Thornton L, Parry JV. Prevalence of antibodies to hepatitis B, hepatitis C, and HIV and risk factors in Irish prisoners: results of a national cross sectional survey. BMJ. 2000;321(7253):78-82. doi:10.1136/bmj.321.7253.78. 
Table 1. Characteristics of the Included Studies of HCV Epidemiology in Iran

\begin{tabular}{|c|c|c|c|c|c|c|c|}
\hline Province & First Author & Ref. & Year of Publication & Year of Study & Mean Age & Number of HCV Cases & Study Sample Size \\
\hline \multirow{2}{*}{ Alborz } & Moradi & $(10)$ & 2018 & 2015 & 39.49 & 145 & 1282 \\
\hline & Sharafi & $(15)$ & 2019 & $2017-2018$ & 36.5 & 106 & 1788 \\
\hline \multirow{5}{*}{ Azerbaijan, East } & Asgari & $(16)$ & 2008 & 2003 & NA & 74 & 472 \\
\hline & Asgari & $(16)$ & 2008 & 2002 & NA & 104 & 517 \\
\hline & Asgari & (16) & 2008 & 2000 & NA & 115 & 480 \\
\hline & Moradi & (10) & 2018 & 2015 & 39.49 & 11 & 297 \\
\hline & Naghili & $(17)$ & 2012 & 2007 & 31.3 & 55 & 192 \\
\hline \multirow{2}{*}{ Bushehr } & Asgari & (16) & 2008 & 2002 & NA & 166 & 403 \\
\hline & Asgari & $(16)$ & 2008 & 2001 & NA & 147 & 355 \\
\hline \multirow{2}{*}{$\begin{array}{l}\text { Chaharmahal and } \\
\text { Bakhtiari }\end{array}$} & Tajbakhsh & $(18)$ & 2008 & NA & 25.8 & 76 & 600 \\
\hline & Moradi & $(11)$ & 2019 & 2016 & 36.29 & 14 & 201 \\
\hline \multirow{2}{*}{ Fars } & Alasvand & (19) & 2015 & 2012 & 37 & 41 & 300 \\
\hline & Moradi & $(10)$ & 2018 & 2015 & 39.49 & 58 & 771 \\
\hline Qazvin & Moradi & (11) & 2019 & 2016 & 36.29 & 60 & 518 \\
\hline \multirow{2}{*}{ Guilan } & Mohtasham Amiri & $(20)$ & 2007 & 2003 & 34.7 & 209 & 460 \\
\hline & Moradi & $(11)$ & 2019 & 2016 & 36.29 & 105 & 1010 \\
\hline Golestan & Khodabakhshi & $(21)$ & 2007 & $2002-2003$ & NA & 28 & 121 \\
\hline \multirow{2}{*}{ Hamadan } & Alizadeh & $(22)$ & 2005 & 2002 & 37.9 & 128 & 427 \\
\hline & Moradi & $(10)$ & 2018 & 2015 & 39.49 & 74 & 538 \\
\hline \multirow{2}{*}{ Hormozgan } & Davoodian & (23) & 2009 & 2002 & 35.4 & 163 & 249 \\
\hline & Moradi & $(11)$ & 2019 & 2016 & 36.29 & 50 & 540 \\
\hline \multirow{7}{*}{ Isfahan } & Alasvand & $(19)$ & 2015 & 2012 & 37 & 101 & 300 \\
\hline & Asgari & $(16)$ & 2008 & 2004 & NA & 51 & 98 \\
\hline & Asgari & $(16)$ & 2008 & 2003 & NA & 144 & 250 \\
\hline & Ataei & (24) & 2011 & NA & 32 & 644 & 1485 \\
\hline & Kassaian & $(25)$ & 2012 & 2009 & 32.6 & 392 & 943 \\
\hline & Nokhodian & (26) & 2012 & $2008-2009$ & 16.59 & 7 & 160 \\
\hline & Nokhodian & $(27)$ & 2012 & 2009 & 34.54 & 12 & 163 \\
\hline $\begin{array}{l}\text { Isfahan, Lorestan, and } \\
\text { Chaharmahal and } \\
\text { Bakhtiari }\end{array}$ & Javadi & (28) & 2006 & 2003 & & 513 & 1431 \\
\hline \multirow{2}{*}{ Kerman } & Alasvand & (19) & 2015 & 2012 & 37 & 10 & 312 \\
\hline & Moradi & $(10)$ & 2018 & 2015 & 39.49 & 34 & 455 \\
\hline \multirow{5}{*}{ Kermanshah } & Alasvand & $(19)$ & 2015 & 2012 & 37 & 53 & 400 \\
\hline & Asgari & $(16)$ & 2008 & 2001 & NA & 353 & 1052 \\
\hline & Asgari & $(16)$ & 2008 & 2004 & NA & 349 & 896 \\
\hline & Khademi & (29) & 2019 & 2017 & 35.52 & 230 & 1034 \\
\hline & Moradi & (11) & 2019 & 2016 & 36.29 & 76 & 576 \\
\hline
\end{tabular}




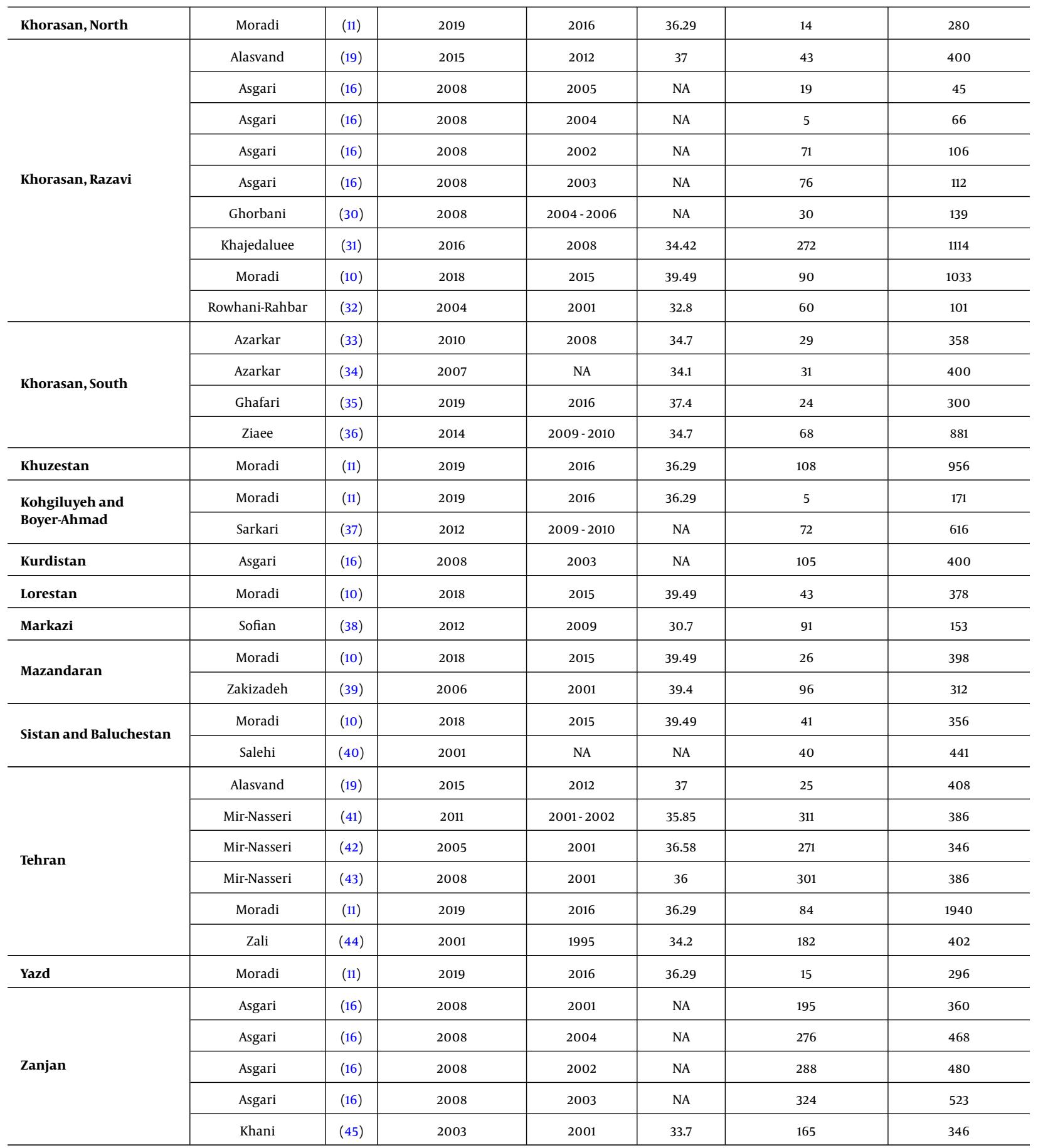

